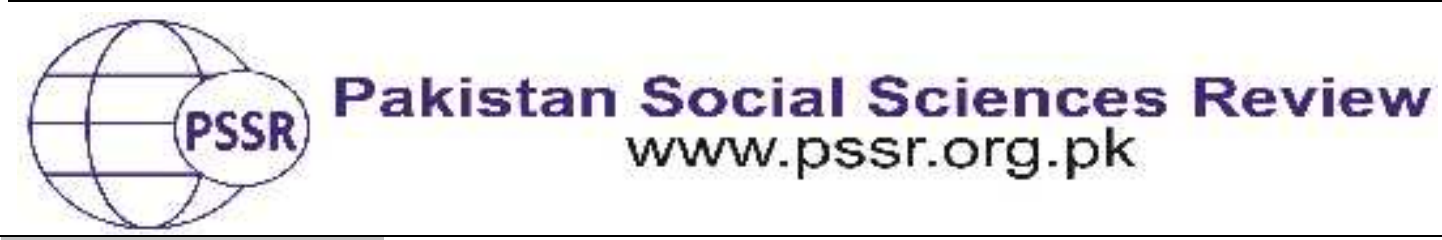

RESEARCH PAPER

\title{
Impact of Promotional Tools on Consumer Buying Decisions in Online Purchasing
}

\author{
Hafiz Muhammad Saad ${ }^{* 1}$ Dr. Muhammad Asim²Salman Manzoor ${ }^{3}$
}

1. MBA Student, Karachi University Business School (KUBS), University of Karachi, Sindh, Pakistan

2. Chairman KUBS, Karachi University Business School (KUBS), University of Karachi, Sindh, Pakistan

3. Ph. D. Scholar, Assistant Professor, Karachi University Business School (KUBS), University of Karachi, Sindh, Pakistan

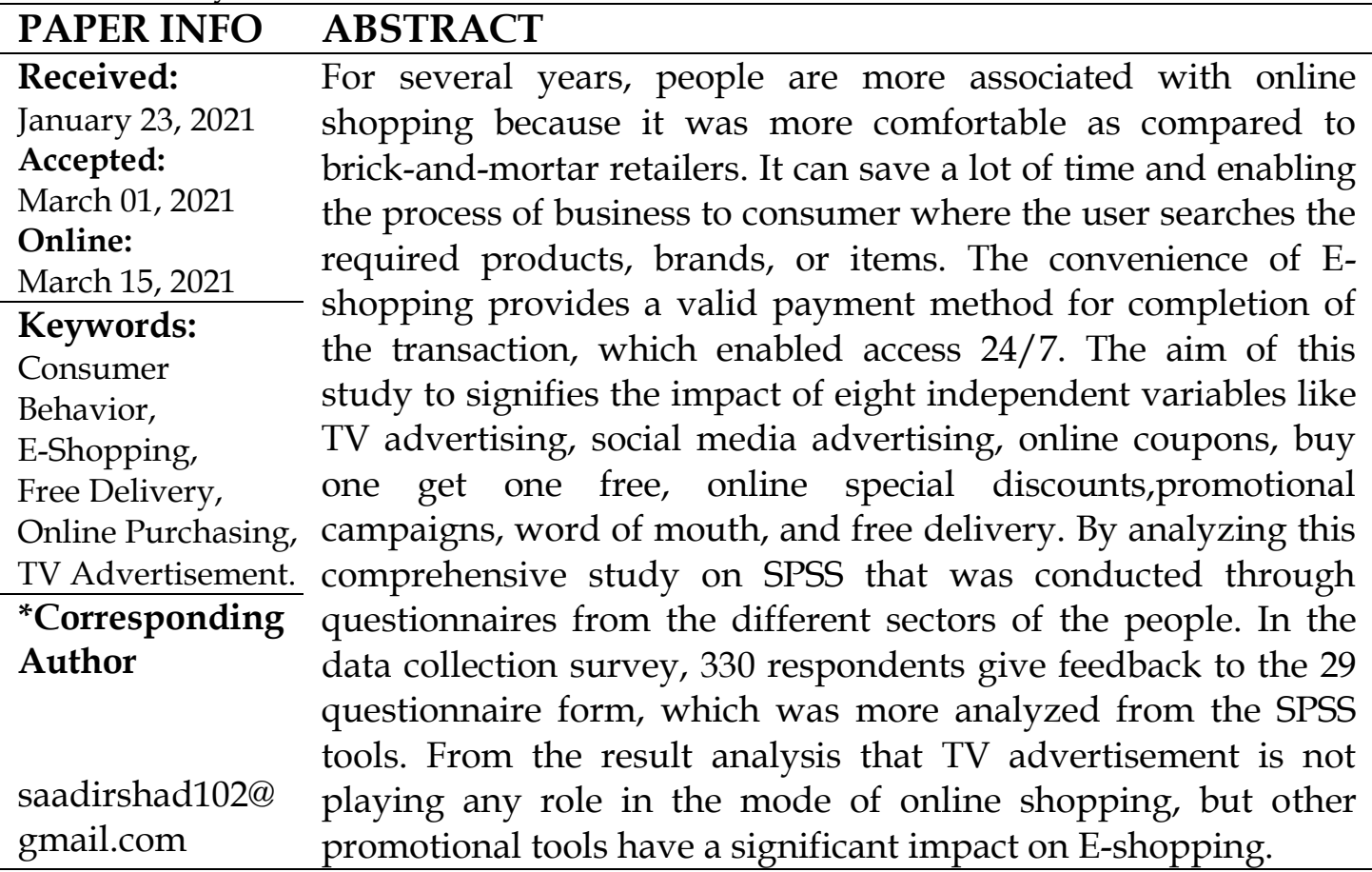

\section{Introduction}

The technique of marketing in a digital environment, customer buying decision is not influenced by the brand or firm attraction. When the consumer takes a buying decision, it is more concerned with a search engine, recommendation, online reviews, and other information. Recently, the growing effect of digital interaction on consumer mind and buying decision from the various interactive promotional tools. In this way, people not only aware of the product information from social media or other techniques but also show references for the problems and solutions related to past issues (Ghosh, 2019) 
Where the presence of E-shopping was increased day by day, the factor of risks was also raised due to trust issues which were impact upon the buying decision of the consumers. They are more concerned about security, financial losses, and performance risks in online shopping rather than offline shopping. The customer who engaged in online shopping faced more risk as compared to stores(Rungsrisawat,Joemsittiprasert, \&amp; Jermsittiparsert, 2019). Some factors influenced the buying decision in e-shopping. Firstly, people did not recognize whether this product was needed by the customer, not a confirmation for after saleservice, and sometimes the buyer did not understand the e-channel process correctly and caused confusion(Khan, Khan, \&amp; Zubair, 2019). Maintaining the trust of the customers is another important aspect for the online retailer through the digital environment. Not necessarily that product design and ideas are met with the customer's expectation. Not only the promotional tools to ensure Customer purchase intention but also increased sales over the internet(Chandra, Mazumdar, \&amp; Suman, 2018) .

Thus, various promotional tools used by online retailers are ultimately the outcome for high sales and customer invitation. Those online retailers are also putting their effort into marketing which relates to customer acquisition by which ultimately enhanced the performance and profit by which the company gains a competitive advantage in front of their rivalries. However, the promotional tools can give benefits to the consumers to think and evaluate brand identity and awareness before purchasing. Similarly, different types of promotional tools are providing marketer analysis by which their sales were increased and knew the consumer's first choices before purchasing online. (Shamout, 2016) These tools include TV advertisement, social media advertisement, online coupons, online special discounts, buy-one-get-one-free, promotional campaigns, free delivery and word of mouth. Different kinds of promotion tactics are used by the seller to boost their sales and retain brand loyalty (Bucko, Kakalejčík, Ferencová, \&amp; Wright, 2018).

\section{Literature Review}

\section{TV Advertisement}

Today, no one escaped from the wide influence of mass media, especially television where the retailers are widely used for advertising for accelerating the business and make a strong product image in front of the consumers. Therefore, companies 44 per cent spend on TV advertisements as compare to other mass media because it has a positive effect on commercial and online advertisement is increased sales. Hence, the consumer is more involved in the commercial and engaged with the content and quality of the message delivered through the commercials (Sama, 2019). Even online retailers are not skipping the TV advertisement because it was considering the way of communication between the audiences and make an effective decision for purchasing. The major impact of advertisement on buying decision was associated brand name which was frequently saved in people memory and always reminds their brand association because people are mostly buying a product via online when they get all information about it. It can give messages to millions of 
people and in the different regions which were not possible for single selling the product or even in stores. Through this way, today every big or small organization is used the TV advertisement promotional tool in the online business because they know the significant value and brand image get the customers from those TV commercials like Banking services apps, food delivery apps, and other online retailing are very much influenced from the commercials. People have not to doubt any fraud and risk associated with it. (Awan, Ismail, Majeed, Ghazal, 2016)

\section{Social Advertisement}

Hence, the social media platform was a perfect match with e-commerce, especially in a time of more usage of social like in the outbreak COVID-19. Particularly, YouTube, Facebook, and Instagram creating more ways where the consumer engaged with online shopping. Social platforms more path to buy by watching the videos and scroll the feeds. Thus, brands take advantage of improved acquisition opportunities and customer preferences according to changing decision. Google has made the various transition to increase the presence of e-commerce in the market place. Their advertisement unit is more giant for business earning as Facebook gain rank for achieving $\$ 7$ billion in advertising because the average person spends an hour or 40 minutes per day on social media. (Ricchiardi, 2020). Luckily, it is the biggest benefit for social media that advertisement was paid, but there was no need for investment for social media advertisements. In the upcoming days, a ratio of online shopping was raised more and more people are connected to buying and selling, which creates intense competition. Further, social media advertising gives more potential to reach customers and find the number of ways where the consumers were connected. As mentioned earlier, Facebook was king of all social platforms in advertising because their ad campaign was more advanced as compared to Ad Words. The main strength of Facebook advertisement was powerful, targeting abilities. They find consumer decision by a gain different aspect of on and off data and make interactive ads which engaged the audience most of the time. Similarly, Twitter and LinkedIn were also great places for advertisement where a lot of people are associate and retailer help in increased the followers, or generate traffic. It gives more brand awareness, and millions of professionals were associated with a LinkedIn domain. Through using the social platform, the reliability of the product was enhanced because the user has the ability to reads reviews through the social media platforms before purchasing online.(Alalwan, 2018)

\section{Online Coupons}

Coupons are widely used by marketers as a promotional tool in the consumer product categories. For the past few years, consumers used coupons or vouchers to save money, especially in the economic crisis. Therefore, online retailers are found coupons as a useful medium for advertising products with the help of coupons. The objective of coupons was to increase the sales and customer intention increased while purchasing online for the existing customers and non-existing customers as well. Most online retailers are customized online coupons according to 
customer's preferences by which develop customer loyalty. These customized coupons not only effective for promotional strategies but also lead to positive financial performance. Most of the research found that coupons were a direct positive impact on purchase decision which depended upon the distribution method, type of coupons issued, and sources used for the online coupons. While purchasing online customers have a drastic opportunity to use the online coupons in the COVID-19 where the economic condition was decline and customers were worried about their spending. Unexpected changes in price by using the coupons would give a positive impact on the people spending and budget. Further, one study found that higher discounts using coupons will switch the buying preferences due to cost-saving behavior. In this way, consumer decision towards the coupons is a main dependent variable. Thus, the behavior was dependent upon three main factors include coupon usage, product purchase, and product perception. Although online coupon validity will enhance the customer intention towards the buying decision and set reminders will take advantage for customers to recall the voucher usage (Barat \& Ye, 2015)

\section{Online Special Discount}

Most of the online merchants will face the decision of whether to provide a discount offer, when to give a special discount, and what worth would be decided for discounts. No doubt, offering online discounts would be a powerful weapon for customer loyalty, customer acquisition, and meet sales objectives. But it was important to select the right brand strategy for offering them online special discounts in which include deep discounting, healthy margin for weekly sales might be a good sales technique(Lee \& Chen-Yu, 2018) .. The business owner decides which offer will suit the online business with many experiments, but the best approach was to offer small and measure the outcomes. Hence, there were several types of special discounts, but a percentage-based discount is most popular among online shopping. Further, a gift is also a great way to give additional towards the customers, where the gift was set on a certain volume, price scheme, or via lucky draw. Customer intention of purchasing will also depend upon the discount codes, which was entered during the checkout process. By using the discount codes is helped to succeed in the marketing efforts and the running campaign is also supported online special discounts and impact on sales. These sales offers depends upon weekly or monthly like the Blessed Friday sale, 11.11 sales on Daraz, and other similar sales provided by the online retailers.(Ferreira, 2019)

\section{Buy-one-Get-one(BOGO) Free}

In most of the food products, clothing, and electronics items, the offer of buyone-get-one-free was the most suitable promotion offer for the online purchaser because in one price get two similar things. This promotional offer is attracting the customer, which was not only increased the sales but also worked as welfare. In the current situation of COVID-19, where the people are disturbing emotionally and financially, then it was the right time to offer this deal in online purchasing. The study found that $66 \%$ of people love BOGO among all discount promotions; they 
participate in this offer at least one time in a year. This was a successful marketing technique and helpful in customer buying decisions and persuade customers for buying and raised the business world. Most of the customers prefer quality products with less price, but if the price of the product was less then move to that product. Many studies found that the free offer technique was to bring positive customer perception because gift option like in BOGO maintains the quality perception and enhanced deal value. So in this way, the customer is not worried about the quality of free gifting as in BOGO. It maintains the brand value where the customer purchase the product then also gets a similar product free. The marketer was suggesting that it create value and satisfaction among the customers, which develops repurchase value among the customers.(Jayaraman, Iranmanesh, Kaur, \& Haron, 2013)

\section{Free Delivery}

As the growth of the e-commerce market rapidly, there was a consideration of the importance of shipping fees. From a firm perspective, it was difficult to design and attract customers in terms of shipping charges. Many studies found that as per customer perspective that due to the additional fees of delivery charges, most of the customers avoid purchasing at online methods. They are more attracted to purchase online while free delivery charges. Unless shipping fees are important for both customers and organizations. Most of the companies offer free delivery charges in online shopping when customers exceed the quantity or price of purchasing. Most of the order gets from the free shipping, and 93\% of buyers are engaged when the delivery charges are free. $61 \%$ of people are cancelled their order if there were not found free shipping fees. Therefore, free delivery always appeals to the customer most and definitely to buy more products rapidly.(Kennedy \&Kundu, 2018)

\section{Online Promotional Campaign}

No doubt, an online promotional campaign would a great way to acquire brand image because the campaign was proactive, humorous, entertaining, or dramatically and always remember in the customer's mind. Thus, a campaign was designed in such a way in which compelling messages and content towards the customers. Through the specialized promotional campaigns cover a wide range of brand loyalty towards the customers. Whenever customers forgot the product, there was a unique chance to remind them as Ariel campaign, and Amazon recently used drone technology just appeal the people towards their product and customers are more avail the opportunity via online purchasing especially in the COVID-19. (ExpertPanel, 2020). Online purchasing is definitely increasing from the online campaign interactivity, and many companies were used in a diverse way. Additionally, social media campaign gives a vital role in online purchasing where the brand was interactive directly and warmly with their consumers and enhanced the confidence and trust over the company. 


\section{Word of Mouth}

It was natural phenomena that humans cannot live alone from the beginning and that why share their feeling and experiences which create a decent relationship. The relationship occurs from the trust, and word of mouth was relating to it. It gives satisfaction to the customers, and this promotional tool was also rapidly increasing by the intervention on online shopping, and people give reviews about the product, and now it was become a trend to give an opinion about the product after purchasing it. Customer positive or negative reviews are attached in the word of mouth in which people distribute information to others. It was guidance that gives other points of view, thoughts, and judgment (Hossain, Kabir, \&Rezvi, 2017).Thus, if the organization work on word of mouth, then it was sustained for long-term customer satisfaction and achieved a strong brand image from word of mouth. Word of mouth gives a momentous role in customer buying decision which was attained by the trust and brand image. $90 \%$ of people purchasing online from the reference to the family/friend or directly knowing the people. By maintaining the trust towards the consumers is finding the positive or negative impact decide the product sales.

Hence, the above discussion analyzed the following hypothesis according to the research study:

H1: There is a positive significant relationship between TV advertisement and online buying decision

H2: There is a positive significantrelationship between social media advertisement and online buying decision

H3: There is a positive significantrelationship between online coupons and online buying decision

H4: There is a positive significant relationship between online special discount and online buying decision

H5: There is a positive significant relationship between BOGO and online buying decision

H6: There is a positive significant relationship between the promotional campaign and online buying decision.

H7: $\quad$ There is a positive significant relationship between free delivery and online buying decision.

H8: There is a positive significant relationship between word of mouth and online buying decision. 


\section{Theoretical Framework}

Independent Variables

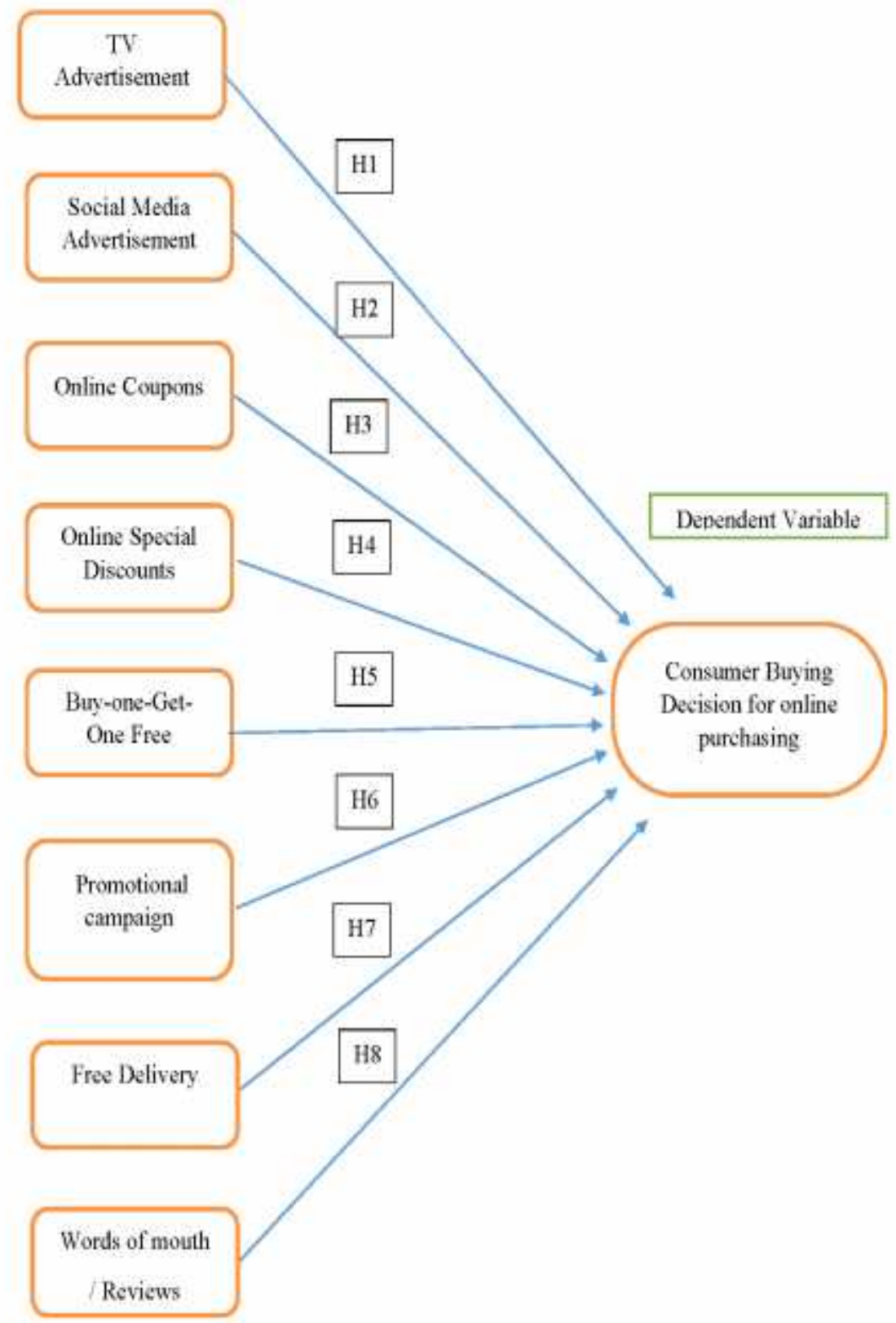




\section{Material and Methods}

The research study examines the online consumer decision from promotional tools. This was targeted toward people who often used the online medium for shopping and how much promotional tools help for supporting in e-shopping. Data survey consisting of 29 questions which were starting from collecting the personal information, education, marital status, and other question related to the dependent and independent variables. Thus, a Likert scale was used in the survey where the option was used as strongly disagree, disagree, neutral, agree, and strongly disagree. The questionnaire was adapted from journal articles and international magazines. Therefore, 330 responses were received from the quantitative data collection, which was further analyzed by the SPSS tool.

\section{Results and Discussion}

\section{Reliability analysis}

The Cronbach alpha method was a commonly used reliability analysis that measures the consistency in the questionnaire, which was made up of the Likert scale items. In this study value of Cronbach alpha is 0.857 , which indicates a high level of internal consistency.

Table 1

\begin{tabular}{cccc}
\hline \multicolumn{3}{c}{ Case Processing Summary } \\
\hline & $\mathrm{N}$ & $\%$ \\
\hline \multirow{3}{*}{ Cases } & Valid & 319 & 98.8 \\
\cline { 2 - 4 } & Excluded & 4 & 1.2 \\
\cline { 2 - 4 } & Total & 323 & 100.0 \\
\hline
\end{tabular}

a. Listwise deletion based on all variables in the procedure

Table 2

\begin{tabular}{cc}
\hline \multicolumn{2}{c}{ Reliability Statistics } \\
\hline Cronbach's Alpha & N of Items \\
\hline .857 & 27 \\
\hline
\end{tabular}

\section{Correlations and hypothesis testing}

Pearson correlation gives information about the effects on one variable to another. In Table 3 analyzed the correlation between TV advertisements and online buying decisions. Where the Pearson Correlation ' $r$ ' value is 0.057, which means negligible relationship exist and also there was no significant correlation because of the value of Sig. (2-tailed) is not less than 0.05 . So H1 is rejected.

Table 3 


\begin{tabular}{cccc}
\hline \multicolumn{4}{c}{ Correlations } \\
\hline \multirow{3}{*}{ TV Advertisement } & $\begin{array}{c}\text { TV } \\
\text { Advertisement }\end{array}$ & $\begin{array}{c}\text { Online Buying } \\
\text { Decision }\end{array}$ \\
\hline & $\begin{array}{c}\text { Pearson } \\
\text { Correlation }\end{array}$ & 1 & .057 \\
\cline { 2 - 4 } & Sig. (2-tailed) & & .312 \\
\cline { 2 - 4 } Online Buying Decision & $\mathrm{N}$ & 322 & 322 \\
\cline { 2 - 4 } & $\begin{array}{c}\text { Pearson } \\
\text { Correlation }\end{array}$ & .057 & 1 \\
\cline { 2 - 4 } & Sig. (2-tailed) & .312 & 322 \\
\cline { 2 - 4 } & $\mathrm{N}$ & 322 & \\
\hline
\end{tabular}

While analyzed in Table 4 Social media advertisement with online buying decision where the Pearson value is 0.265 means weak positive relation but have significant correlation because the value is less than 0.05 . Therefore, a hypothesis was confirmed that social media have a significant impact on online purchasing.

Table 4

\begin{tabular}{|c|c|c|c|}
\hline \multicolumn{4}{|c|}{ Correlations } \\
\hline & & $\begin{array}{c}\text { Social Media } \\
\text { Advertisement }\end{array}$ & $\begin{array}{l}\text { Online Buying } \\
\text { Decision }\end{array}$ \\
\hline \multirow{3}{*}{$\begin{array}{c}\text { Social Media } \\
\text { Advertisement }\end{array}$} & $\begin{array}{c}\text { Pearson } \\
\text { Correlation }\end{array}$ & 1 & $.265^{* *}$ \\
\hline & Sig. (2-tailed) & & .000 \\
\hline & $\mathrm{N}$ & 322 & 322 \\
\hline \multirow{3}{*}{$\begin{array}{l}\text { Online Buying } \\
\text { Decision }\end{array}$} & $\begin{array}{c}\text { Pearson } \\
\text { Correlation }\end{array}$ & $.265^{* *}$ & 1 \\
\hline & Sig. (2-tailed) & .000 & \\
\hline & $\mathrm{N}$ & 322 & 322 \\
\hline
\end{tabular}

In the below Table 5, illustrate the relation between coupons and online buying decision. Therefore, the ' $r$ ' value is 0.270 , which means weak positive relation but Sig. (2-tailed) value is .000, which means less than 0.05 . Thus it was significant correlation exists between coupons and online buying decision.

Table 5

\begin{tabular}{cccc}
\hline & \multicolumn{2}{c}{ Correlations } & \\
\hline & & $\begin{array}{c}\text { Online } \\
\text { Coupons }\end{array}$ & $\begin{array}{c}\text { Online Buying } \\
\text { Decision }\end{array}$ \\
\hline \multirow{3}{*}{ Online Coupons } & Pearson Correlation & 1 & $.270^{* *}$ \\
\cline { 2 - 4 } & Sig. (2-tailed) & 322 & .000 \\
\cline { 2 - 4 } Online Buying Decision & $\mathrm{N}$ & $.270^{* *}$ & 322 \\
\cline { 2 - 4 } & Pearson Correlation & .000 & 1 \\
\cline { 2 - 4 } & Sig. (2-tailed) &
\end{tabular}




$\mathrm{N} \quad 322 \quad 322$

Although, Table 6 shows the relation between special discounts and online buying decision where the ' $r$ ' value of Pearson is 0.387 is a moderate positive correlation, and there was a significant relation between buying decision and special discounts because the value was below 0.05 . Therefore, hypothesis testing was confirmed.

Table 6

\begin{tabular}{|c|c|c|c|}
\hline \multicolumn{4}{|c|}{ Correlations } \\
\hline & & $\begin{array}{l}\text { Online Special } \\
\text { Discounts }\end{array}$ & $\begin{array}{l}\text { Online Buying } \\
\text { Decision }\end{array}$ \\
\hline \multirow{3}{*}{$\begin{array}{l}\text { Online Special } \\
\text { Discounts }\end{array}$} & $\begin{array}{c}\text { Pearson } \\
\text { Correlation }\end{array}$ & 1 & $.387^{* *}$ \\
\hline & Sig. (2-tailed) & & .000 \\
\hline & $\mathrm{N}$ & 322 & 322 \\
\hline \multirow{3}{*}{$\begin{array}{l}\text { Online Buying } \\
\text { Decision }\end{array}$} & $\begin{array}{c}\text { Pearson } \\
\text { Correlation }\end{array}$ & $.387^{* *}$ & 1 \\
\hline & Sig. (2-tailed) & .000 & \\
\hline & $\mathrm{N}$ & 322 & 322 \\
\hline
\end{tabular}

Table 7 compares the relation between BOGO and buying decision. The value of $\mathrm{r}$ is 0.384 , which indicates moderate positive relation and must be a significant correlation exists between two variables.

Table 7

\begin{tabular}{|c|c|c|c|}
\hline \multicolumn{4}{|c|}{ Correlations } \\
\hline & & BOGOF & $\begin{array}{l}\text { Online Buying } \\
\text { Decision }\end{array}$ \\
\hline \multirow{3}{*}{ BOGOF } & Pearson Correlation & 1 & $.384^{* *}$ \\
\hline & Sig. (2-tailed) & & .000 \\
\hline & $\mathrm{N}$ & 322 & 322 \\
\hline \multirow{3}{*}{ Online Buying Decision } & Pearson Correlation & $.384^{* *}$ & 1 \\
\hline & Sig. (2-tailed) & .000 & \\
\hline & $\mathrm{N}$ & 322 & 322 \\
\hline
\end{tabular}

Perhaps, in the below Table 8, special promotional campaigns and buying decision possess strong positive relationships and also lies a significant correlation among the variables. This means promotional campaigns playing a vital role in online purchasing decision over consumers. Similarly, Table 9 correlations between the word of mouth and buying decision were also a strong positive relationship and had a significant relationship among two variables. 
Table 8

\begin{tabular}{|c|c|c|c|}
\hline \multicolumn{4}{|c|}{ Correlations } \\
\hline & & $\begin{array}{l}\text { Special Promotional } \\
\text { Campaigns }\end{array}$ & $\begin{array}{l}\text { Online Buying } \\
\text { Decision }\end{array}$ \\
\hline \multirow[t]{3}{*}{$\begin{array}{l}\text { Special Promotional } \\
\text { Campaigns }\end{array}$} & $\begin{array}{l}\text { Pearson } \\
\text { Correlation }\end{array}$ & 1 & $.603^{* *}$ \\
\hline & Sig. (2-tailed) & & .000 \\
\hline & $\mathrm{N}$ & 322 & 322 \\
\hline \multirow[t]{3}{*}{$\begin{array}{l}\text { Online Buying } \\
\text { Decision }\end{array}$} & $\begin{array}{l}\text { Pearson } \\
\text { Correlation }\end{array}$ & $.603^{* *}$ & 1 \\
\hline & Sig. (2-tailed) & .000 & \\
\hline & $\mathrm{N}$ & 322 & 322 \\
\hline
\end{tabular}

Table 9

\begin{tabular}{cccc}
\hline \multicolumn{3}{c}{ Correlations } \\
\hline & \multicolumn{1}{c}{$\begin{array}{c}\text { Words of Mouth / } \\
\text { Reviews }\end{array}$} & $\begin{array}{c}\text { Online Buying } \\
\text { Decision }\end{array}$ \\
\hline \multirow{2}{*}{$\begin{array}{c}\text { Words of Mouth } \\
\text { Reviews }\end{array}$} & $\begin{array}{c}\text { Pearson } \\
\text { Correlation }\end{array}$ & 1 & $.427^{* *}$ \\
\cline { 2 - 4 } & Sig. (2-tailed) & .000 \\
\hline \multirow{2}{*}{$\begin{array}{c}\text { Online Buying } \\
\text { Decision }\end{array}$} & $\begin{array}{c}\text { Pearson } \\
\text { Correlation }\end{array}$ & $.427^{* *}$ & 322 \\
\cline { 2 - 4 } & Sig. (2-tailed) & .000 & 1 \\
\cline { 2 - 4 } & $\mathrm{N}$ & 322 & 322 \\
\hline
\end{tabular}

In the last correlation Table 10, the Pearson value shows the weak strong positive relation, but it was also a significant correlation exist due to less than a value of 0.05 .

Table 10

\begin{tabular}{cccc}
\hline & \multicolumn{2}{c}{ Correlations } & \\
\hline & \multicolumn{1}{c}{$\begin{array}{c}\text { Free } \\
\text { Delivery }\end{array}$} & $\begin{array}{c}\text { Online Buying } \\
\text { Decision }\end{array}$ \\
\hline \multirow{3}{*}{ Free Delivery } & $\begin{array}{c}\text { Pearson } \\
\text { Correlation }\end{array}$ & 1 & $.271^{* *}$ \\
\cline { 2 - 4 } & Sig. (2-tailed) & .000 \\
\cline { 2 - 4 } & $\mathrm{N}$ & 322 & 322 \\
\hline \multirow{2}{*}{$\begin{array}{c}\text { Online Buying } \\
\text { Decision }\end{array}$} & $\begin{array}{c}\text { Pearson } \\
\text { Correlation }\end{array}$ & $.271^{* *}$ & 1 \\
\cline { 2 - 4 } & Sig. (2-tailed) & .000 & 322 \\
\cline { 2 - 4 }
\end{tabular}

\section{Regression Analysis}


In the given analysis of the study used multiple regression which was an extension of linear regression. It was used in the prediction of a variable based upon the value of one or more variables. The variable which wants to predict from the independent variables which are predictors is dependent variable in multiple regression.

Table 11

\begin{tabular}{|c|c|c|c|c|c|c|c|c|c|}
\hline \multicolumn{10}{|c|}{ Model Summary } \\
\hline \multirow[b]{2}{*}{ Model } & \multirow[b]{2}{*}{$\mathrm{R}$} & \multirow[b]{2}{*}{$\begin{array}{c}\mathrm{R} \\
\text { Square }\end{array}$} & \multirow[b]{2}{*}{$\begin{array}{l}\text { Adjusted } \\
\text { R Square }\end{array}$} & \multirow{2}{*}{$\begin{array}{l}\text { Std. An } \\
\text { error of } \\
\text { the } \\
\text { Estimate }\end{array}$} & \multicolumn{5}{|c|}{ Change Statistics } \\
\hline & & & & & $\begin{array}{l}\text { R } \\
\text { Square } \\
\text { Change }\end{array}$ & $\begin{array}{c}\mathrm{F} \\
\text { Change }\end{array}$ & df1 & df2 & $\begin{array}{c}\text { Sig. F } \\
\text { Change }\end{array}$ \\
\hline 1 & $.712^{a}$ & .507. & .495 & .50935 & .507 & 40.292 & 8 & 313 & .000 \\
\hline \multicolumn{10}{|c|}{$\begin{array}{l}\text { a. Predictors: (Constant), Free Delivery, TV Advertisement, Social Media } \\
\text { Advertisement, Online Special Discounts, Special Promotional Campaigns, Online } \\
\text { Coupons, Words of Mouth, BOGOF }\end{array}$} \\
\hline
\end{tabular}

As shown in the model summary table, the value of R square shows that $50.7 \%$ of the variance is associated with the predictor as (free delivery, TV advertisement, social media advertisement, online discount, special promotional campaign, online coupons, word of mouth, and BOGO). It was said that the independent variable predicts $50.7 \%$ variability in the dependent variable towards the online buying decision.

Table 12

\begin{tabular}{|c|c|c|c|c|c|c|c|c|}
\hline \multicolumn{9}{|c|}{ Coefficients } \\
\hline & \multirow[b]{2}{*}{ Model } & \multicolumn{2}{|c|}{$\begin{array}{l}\text { Unstandardized } \\
\text { Coefficients }\end{array}$} & \multirow{2}{*}{$\begin{array}{c}\begin{array}{c}\text { Standardized } \\
\text { Coefficients }\end{array} \\
\text { Beta }\end{array}$} & \multirow[t]{2}{*}{$\mathrm{t}$} & \multirow[t]{2}{*}{ Sig. } & \multicolumn{2}{|c|}{$\begin{array}{c}95.0 \% \\
\text { Confidence } \\
\text { Interval for B }\end{array}$} \\
\hline & & B & $\begin{array}{l}\text { Std. } \\
\text { Error }\end{array}$ & & & & $\begin{array}{l}\text { Lower } \\
\text { Bound }\end{array}$ & $\begin{array}{l}\text { Upper } \\
\text { Bound }\end{array}$ \\
\hline & (Constant) & .712 & .221 & & 3.224 & .001 & .277 & 1.146 \\
\hline & $\begin{array}{l}\text { TV } \\
\text { Advertisement } \\
\text { X1 }\end{array}$ & -.038 & .030 & -.052 & -1.273 & .204 & -.096 & .021 \\
\hline & $\begin{array}{c}\text { Social Media } \\
\text { Advertisement } \\
\text { X2 }\end{array}$ & .075 & .036 & .088 & 2.107 & .036 & .005 & .145 \\
\hline 1 & $\begin{array}{c}\text { Online Coupons } \\
\text { X3 }\end{array}$ & .035 & .033 & .048 & 1.057 & .291 & -.030 & .100 \\
\hline & $\begin{array}{l}\text { Online Special } \\
\text { Discounts X4 }\end{array}$ & .109 & .034 & .143 & 3.246 & .001 & .043 & .175 \\
\hline & BOGOF X5 & .081 & .034 & .114 & 2.396 & .017 & .015 & .148 \\
\hline & $\begin{array}{c}\text { Special } \\
\text { Promotional } \\
\text { Campaigns X6 }\end{array}$ & .312 & .030 & .454 & 10.362 & .000 & .252 & .371 \\
\hline
\end{tabular}




\begin{tabular}{cccccccc}
$\begin{array}{c}\text { Words of Mouth } \\
\text { X7 }\end{array}$ & .226 & .040 & .250 & 5.582 & .000 & .146 & .305 \\
\hline Free Delivery X8 & -.015 & .034 & -.021 & -.452 & .652 & -.082 & .052 \\
\hline
\end{tabular}

Based on the above coefficient Table 12, it was analyzed that TV advertisement, online coupons, and free delivery are insignificant because there values above 0.05 . On the other hand, the beta value of social media advertisement, online special discount, BOGO, special promotional campaigns, and word of mouth, i.e., $0.75,0.109,0.081,0.312,0.226$ respectively which all are significant, and therefore the equation is derived as:

\section{$Y=0.712+0.75 \times 2+0.109 \times 4+0.081 X 5+0.312 \times 6+0.226 \times 7$}

Hence, the above equation shows that social media advertisement, online special discount, BOGO, promotional campaign, and word of mouth are the best possible predictor for online purchasing decision.

In the above data analysis, data were analyzed by two models. Correlation matrix and multiple regression. Hence, it shows that independent variables have a positive correlation with dependent variables. The correlation matrix shows that every independent variable is a positive correlation and significant except H1 analysis. But when we analyzed the multiple regression to find the highest impact of the independent variables, then we find social media advertisement, special discount, promotional campaigns, online coupons, free delivery, BOGO, and word of mouth are best predictors among in the independent variables. The TV advertisement impact did not influence upon the intention of online purchasing of consumers. Therefore $\mathrm{H} 0$ and $\mathrm{H} 1$ are rejected.

\section{Descriptive Analysis}

This section uncovers the descriptive analysis of the study wherein part 1 consisting of demographic information of the respondents which was analyzed in the below respondent table. The participation of male respondents is $50.6 \%$, and female was $49.4 \%$, of which $64 \%$ were single status, and married respondents are $36 \%$. Additionally, the table illustrates that the highest level of age group was 10-20 years respondent who participate in the survey which was $69.9 \%$ and $50 \%$ respondent are university students. From the employment status analyzed that most participants are doing a private job.

Table 13

\begin{tabular}{cccc}
\hline & \multicolumn{3}{c}{ Respondents Profile } \\
\hline \multirow{2}{*}{ Gender } & Frequency & Per cent \\
\cline { 2 - 4 } & Male & 163 & 50.6 \\
\hline \multirow{2}{*}{ Marital } & Female & 159 & 49.4 \\
\hline
\end{tabular}




\begin{tabular}{|c|c|c|c|}
\hline Status & Married & 116 & 36.0 \\
\hline \multirow{5}{*}{ Age } & $10-20$ & 40 & 12.4 \\
\hline & $20-30$ & 225 & 69.9 \\
\hline & $30-40$ & 41 & 12.7 \\
\hline & $40-50$ & 11 & 3.4 \\
\hline & Above 50 & 5 & 1.6 \\
\hline \multirow{5}{*}{ Education } & Intermediate & 45 & 14.0 \\
\hline & Bachelors & 161 & 50.0 \\
\hline & Masters & 98 & 30.4 \\
\hline & M.Phil. & 17 & 5.3 \\
\hline & $\mathrm{PhD}$ & 1 & .3 \\
\hline \multirow{6}{*}{ Status } & Un-Employed & 29 & 9.0 \\
\hline & $\begin{array}{c}\text { Employed / } \\
\text { Private Job }\end{array}$ & 182 & 56.5 \\
\hline & $\begin{array}{l}\text { Government } \\
\text { Job }\end{array}$ & 5 & 1.6 \\
\hline & Business & 24 & 7.5 \\
\hline & Student & 64 & 19.9 \\
\hline & Housewife & 18 & 5.6 \\
\hline
\end{tabular}

In the below table depict the gender and buying frequency of the consumers which show that $37.9 \%$ are single male purchase once in a month whereas a single female is $34 \%$ who also purchased once in a month. Similarly, married males and females also purchase once a month.

Table 14: Gender * Buying Frequency * Marital Status Cross tabulation

\begin{tabular}{|c|c|c|c|c|c|c|c|c|c|c|}
\hline \multirow{2}{*}{\multicolumn{3}{|c|}{ Marital Status }} & \multicolumn{8}{|c|}{ Buying Frequency } \\
\hline & & & Not & Once in a & Occasion & Once & $\begin{array}{c}\text { Once } \\
\text { in a }\end{array}$ & $\begin{array}{l}\text { Once } \\
\text { in a }\end{array}$ & $\begin{array}{l}\text { Once } \\
\text { in a }\end{array}$ & $\begin{array}{l}\text { Once } \\
\text { in a }\end{array}$ \\
\hline \multirow{2}{*}{ Single } & \multirow{2}{*}{ Gender } & Male & $1.0 \%$ & & $1.9 \%$ & $15.5 \%$ & $31.1 \%$ & $1.0 \%$ & $37.9 \%$ & $11.7 \%$ \\
\hline & & Female & $1.9 \%$ & $1.0 \%$ & $1.9 \%$ & $18.4 \%$ & $30.1 \%$ & & $34.0 \%$ & $12.6 \%$ \\
\hline \multirow{2}{*}{ Married } & \multirow{2}{*}{ Gender } & Male & $3.3 \%$ & & $3.3 \%$ & $18.3 \%$ & $28.3 \%$ & & $33.3 \%$ & $13.3 \%$ \\
\hline & & Female & & $3.6 \%$ & $5.4 \%$ & $17.9 \%$ & $26.8 \%$ & & $42.9 \%$ & $3.6 \%$ \\
\hline
\end{tabular}


Figure 1:

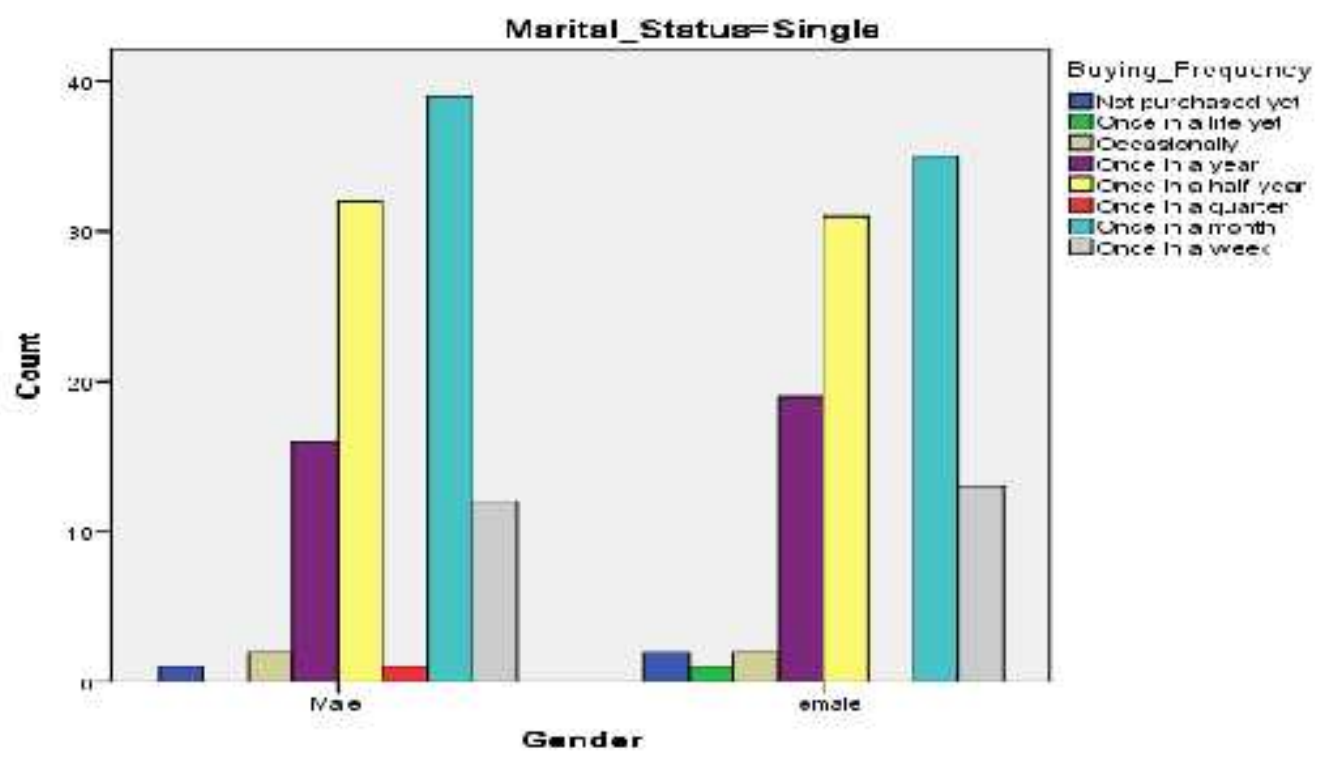

Figure 2:

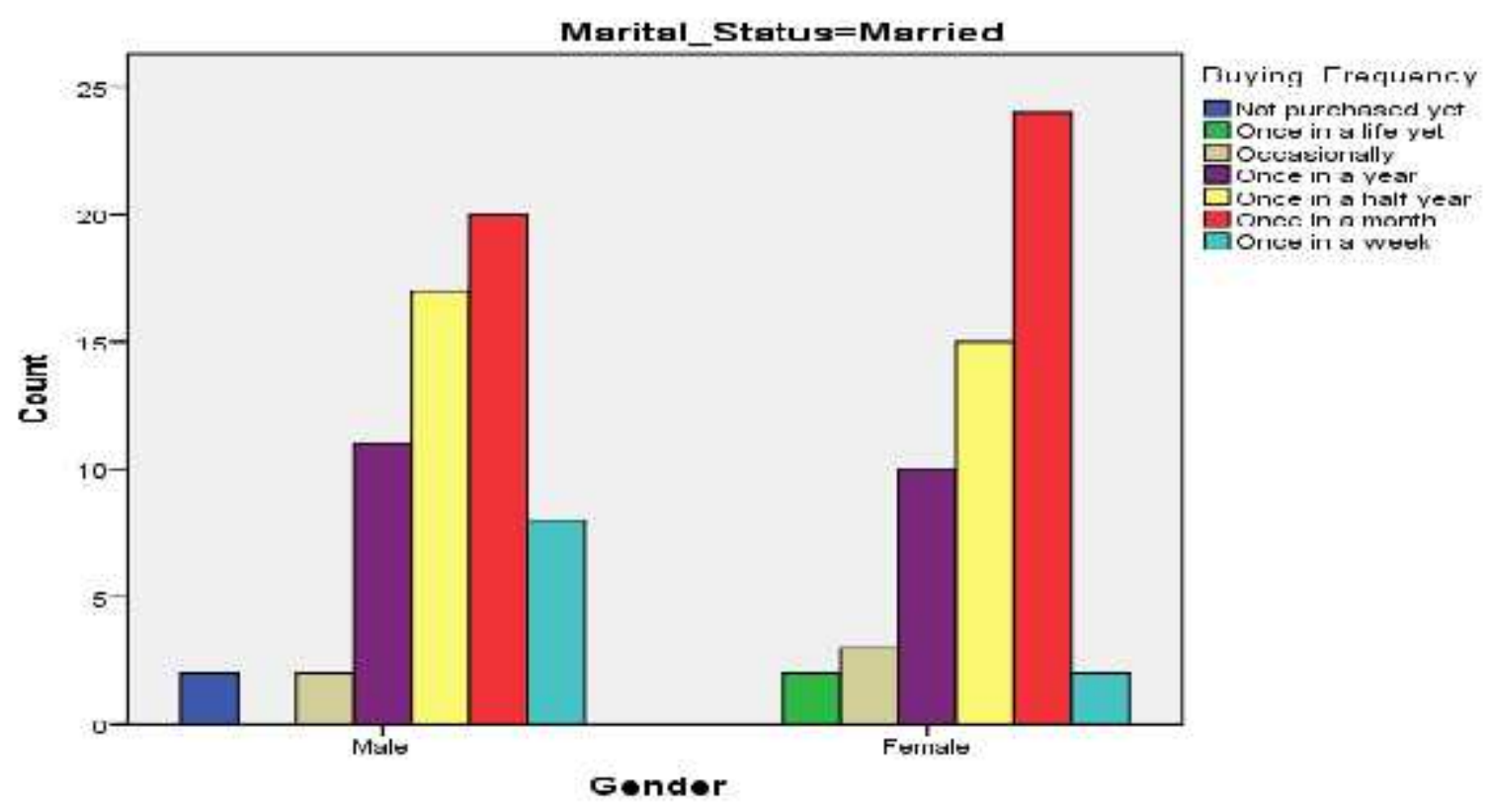

The below table analyzed the purchasing factor in regards to age and gender. In the data find that $37.5 \%$ male who age group lies in 10-20 purchase once in a half year, 20-30 age group purchase once in a month, 34.5\% male age group 30-40 once in 
a half year, $62.5 \%$ age group 40-50 male purchase once in a month and above 50 age was also purchased once in a half year. On the other hand, $40.6 \%$ of the female age group 10-20 purchase once a month. Similarly, 35.7\% of females age $20-30,41.7 \%$ of females age 30-40 also purchase once a month. But at the age of $40-50$ female is purchasing buying frequency was the same. Therefore, we come out with the outcome that females are more frequently take buying decisions as compare to males regarding any age group.

Table 15

Age * Buying Frequency * Gender Cross tabulation

\begin{tabular}{|c|c|c|c|c|c|c|c|c|c|c|}
\hline \multirow{2}{*}{ 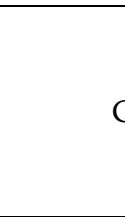 } & \multirow{2}{*}{ Gende } & & \multicolumn{8}{|c|}{ Buying_Frequency } \\
\hline & & & Not & Once & Pronainolly & Once & $\begin{array}{c}\text { Once } \\
\text { in a }\end{array}$ & Once in & Once & Once \\
\hline \multirow{5}{*}{ Male } & \multirow{5}{*}{ Age } & $10-20$ & & & & $12.5 \%$ & $37.5 \%$ & & $37.5 \%$ & $12.5 \%$ \\
\hline & & $20-30$ & $1.8 \%$ & & $3.5 \%$ & $17.7 \%$ & $27.4 \%$ & & $38.9 \%$ & $10.6 \%$ \\
\hline & & $30-40$ & & & & $17.2 \%$ & $34.5 \%$ & & $24.1 \%$ & $24.1 \%$ \\
\hline & & $40-50$ & & & & & $25.0 \%$ & $12.5 \%$ & $62.5 \%$ & \\
\hline & & $\begin{array}{c}\text { Above } \\
50\end{array}$ & $20.0 \%$ & & & $20.0 \%$ & $60.0 \%$ & & & \\
\hline \multirow{4}{*}{ Female } & \multirow{4}{*}{ Age } & $10-20$ & $3.1 \%$ & & $3.1 \%$ & $15.6 \%$ & $18.8 \%$ & & $40.6 \%$ & $18.8 \%$ \\
\hline & & $20-30$ & $.9 \%$ & $1.8 \%$ & $3.6 \%$ & $18.8 \%$ & $32.1 \%$ & & $35.7 \%$ & $7.1 \%$ \\
\hline & & $30-40$ & & & & $25.0 \%$ & $25.0 \%$ & & $41.7 \%$ & $8.3 \%$ \\
\hline & & $40-50$ & & $33.3 \%$ & & & $33.3 \%$ & & $33.3 \%$ & \\
\hline
\end{tabular}

Figure 3:

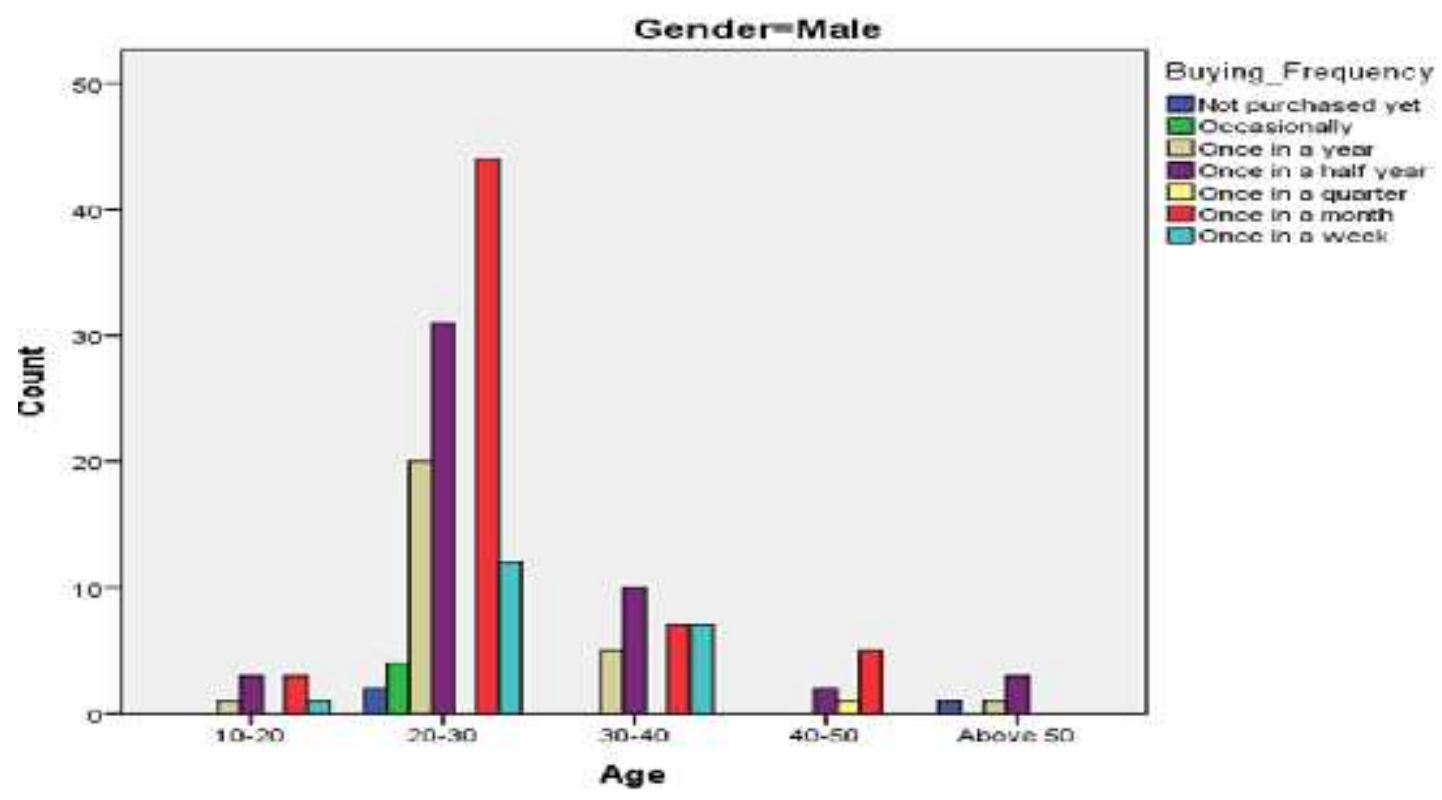


Figure 4:

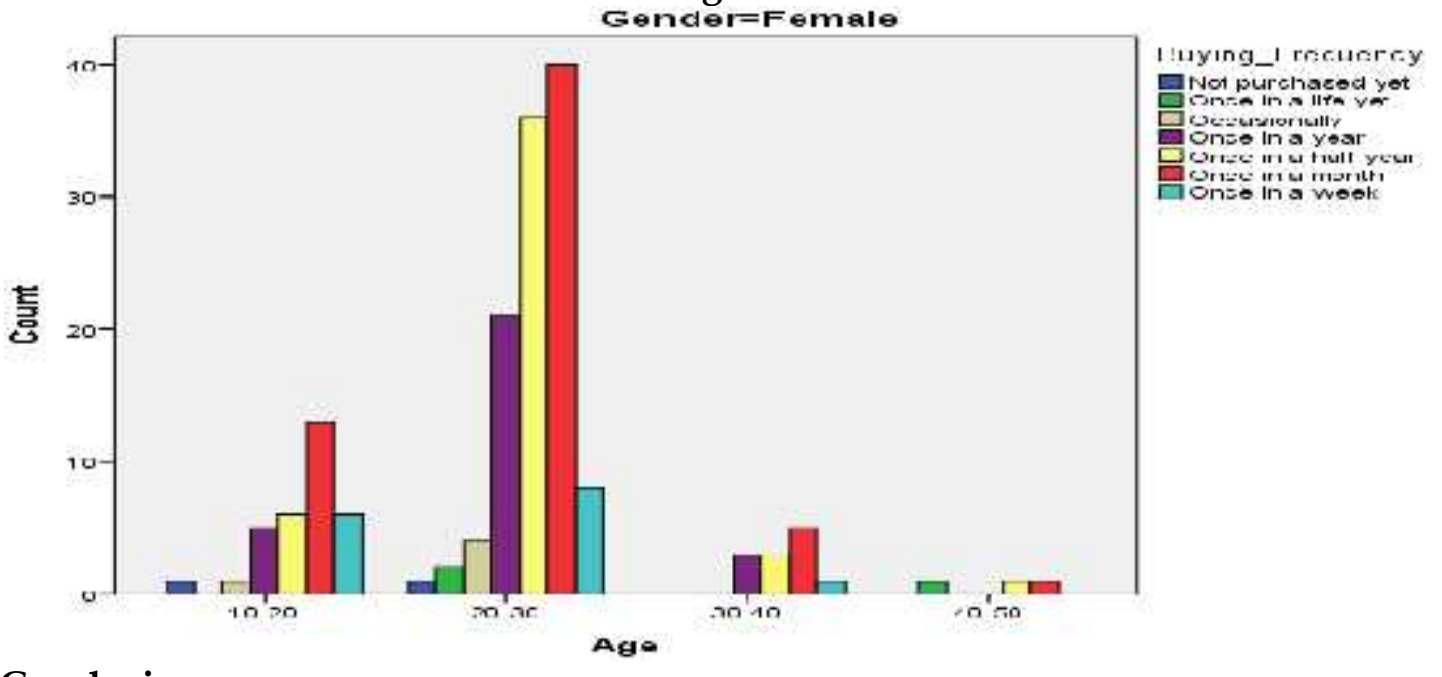

\section{Conclusion}

In the last, the objective of this study was to conduct analyzed the impact of eight promotional tools on the consumers buying decision on online purchasing. In this study, 330 participants fill the survey form where 159 are females, and 163 are males. As in the current situation of COVID-19, it was analyzed by the researchers that online purchasing was increased due to social and environmental restrictions. In Thus in this regard, the online business in the future is rapidly growing because of the recent pandemic and economic downfall, organizations utilized maximum benefit from digital technology. Thus, it shows E-business has a bright future in the market.

\section{Recommendations}

Thus the regression equation shows that people are more influenced towards social media advertisement, special coupons, BOGO, promotional campaign, and word of mouth before online purchasing. Therefore, necessary for marketers to need to give more advancement in special coupon packages, campaigns, and buy one get one free advertising. Moreover, attractive social media advertising also provides a positive role in the profit of online business. More importantly, people believe in the word of mouth that why they read reviews before purchasing any item in online shopping, good reviews always gain more profit and success for the organization. 


\section{References}

Alalwan, A. A. (2018, October). Investigating the impact of social media advertising features on customer purchase intention. International Journal of Information Management, 65-77.

Awan, A. G., Ismail, M., Majeed, C. F., \& Ghazal, F. (2016). Effects of Advertisement on Consumer's Buying Behaviour with References to FMCGs in Southern PunjabPakistan. Journal of Marketing and Consumer Research, 22-30.

Barat, S., \& Ye, L. (2015). Effects of Coupons on Consumer Purchase Behavior: A MetaAnalysis. Journal of Marketing Development and Competitiveness, 6(5), 133-144.

Bucko, J., Kakalejčík, L., Ferencová, M., \& Wright, L. T. (2018, July 23). Online shopping: Factors that affect consumer purchasing behaviour. Cogent Business $\mathcal{E}$ Management, $5(1), 1-15$.

Chandra, S., Mazumdar, S., \& Suman, U. (2018, October). Impact of sales promotional tools on the consumers buying behaviour: Study-related with apparel retailing business. International Journal of Applied Research, 4(10), 23-29.

Ferreira, C. (2019). 19 Ways to Use Offers, Coupons, Discounts, and Deals to Generate More Sales, Forbes.

ExpertPanel. (2020, July 20). 10 Well-Executed Recent Ad Campaigns With Perfect Delivery, Forbes.

Ghosh, R. (2019, December). Understanding Consumers' Behaviour Towards Online Shopping: The Unified Theory Of Acceptance \& Use Of Technology (Utaut) Perspective. Journal of the Gujrat Research Society, 21(13), 817-837.

Hossain, M. M., Kabir, S., \& Rezvi, R. I. (2017). Influence of Word of Mouth on Consumer Buying Decision: Evidence from Bangladesh Market. European Journal of Business and Management, 9(12), 38-45.

Jayaraman, K., Iranmanesh, M., Kaur, M. D., \& Haron, H. (2013, March 20). Consumer Reflections on "Buy One Get One Free" (BOGO) Promotion Scheme-An Empirical Study in Malaysia. Research Journal of Applied Sciences, Engineering and Technology, 5(9),2740-2747.

Kennedy, E. N., \& Kundu, G. K. (2018). Influence Of Delivery Charges And Time On Online Purchase Decision. International Journal of Pure and Applied Mathematics, 118(18), 4393-4404.

Khan, M. A., Khan, A., \& Zubair, S. S. (2019). Online Buying Behavior: Prospects for Online Sale Promotions Strategies in Pakistan. UCP Management Review, 3(1), 25-40. 
Lee, J. E., \& Chen-Yu, J. H. (2018, February 15). Effects of \a price discount on consumers' perceptions of savings, quality, and value for apparel products: mediating effect of price discount affect. International Journal of Interdisciplinary Research, 5(13), 2-21.

Ricchiardi, A. (2020, November 10). The Next Era Of Social Media Marketing Is Here, Forbes.

Rungsrisawat, S., Joemsittiprasert, W., \& Jermsittiparsert, K. (2019). Factors Determining Consumer Buying Behaviour in Online Shopping. International Journal of Innovation, Creativity and Change, 8(8), 222-237.

Sama, R. (2019, February 13). Impact of Media Advertisements on Consumer Behaviour. Journal of Creative Communication, 14(1), 54-68.

Shamout, M. D. (2016, January). The Impact of Promotional Tools on Consumer Buying Behavior in Retail Market. International Journal of Business and Social Science,7(1), 7585. 